Research, part of a Special Feature on Private Land Conservation - Landowner Motives, Policies, and Outcomes of Conservation Measures in Unprotected Landscapes

\title{
Perpetual private land conservation: the case for outdoor recreation and functional leisure
}

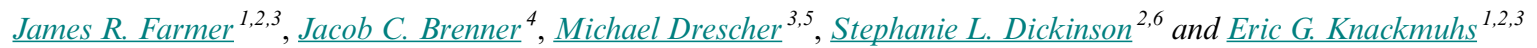

\begin{abstract}
As natural areas, agricultural lands, and open spaces continue to be developed at unprecedented rates, it is important for land conservation professionals to understand the individuals who might play a role in permanently protecting these lands and their ecological services. Many factors have been shown to influence land protection decisions among private owners, including land-use activities, demographic characteristics, and environmental intention and behavior. With the hypothesis that individuals already involved in land conservation programs would be candidates for permanent protection, we set out to model conservation easement decisions within a group of participants in southern Indiana's Classified Forest and Wildlands Program (ICFWP). We used a mailed questionnaire to survey 500 landowners, garnering 308 responses, about their interest in conservation easements. Our results indicated significant positive relationships between interest in conservation easements with variables representing perception of landscape change, outdoor recreation behavior as an adult, and environmental organization membership. By better understanding the ways these factors promote permanent land-use decisions, land conservation professionals can better allocate limited resources through strategic investments in targeting and outreach.
\end{abstract}

Key Words: conservation easements; functional leisure; Indiana Classified Forest and Wildlands; land trusts; land use; private land conservation

\section{INTRODUCTION}

Scientists estimate that because of population growth and urban expansion, global urban land-cover will increase by 1.2 million $\mathrm{km}^{2}$ in the near future, threatening habitats, biodiversity, and carbon sequestration (Seto et al. 2012). In addition, low-density residential development (Suarez-Rubio et al. 2011) and the conversion of wetlands to farmland (Van Asselen et al 2013) and rangeland to tillable acreage (Byrd et al. 2015) are becoming increasingly important issues. These land cover changes will diminish the vital ecosystem services provided by intact natural areas (Lee 2005). Because many of these areas are privately owned, governmental land acquisition can be only one part of a comprehensive conservation solution (Norton 2000, Butchart et al. 2010), and its role has decreased in recent decades. Private land conservation (PLC) mechanisms, on the other hand, are becoming an increasingly important way to address these new challenges (Farmer et al. 2015). In the United States, where private ownership accounts for $65 \%$ of land in the contiguous 48 states and $82 \%$ in the eastern part of the country (128.7 million ha; U.S. Forest Service 2001), PLC is perhaps the most promising avenue for protecting open space, natural areas, and ecosystem services on a large scale (Trombulak and Baldwin 2010).

One PLC mechanism that works to permanently protect privately owned open space and natural areas is a conservation easement. Conservation easements represent negotiated, legally binding agreements between private property owners and conservation organizations, and they are often used to protect landscapes with ecological, historical, cultural, or recreational significance (Gustanski and Squires 2000, Farmer et al. 2011a). Conservation easements are a permanent, private land protection mechanism that divides and distributes certain property rights as agreed upon by the landowner and a third-party land conservation organization. Land is protected perpetually from development, and often times other rights are sold or given to the third party, rights such as timber, hunting, and mineral extraction (Gustanski and Squaires 2000). Land protected through conservation easements remains privately owned while state and local governments continue to receive revenue from property taxes (Land Trust Alliance [LTA] 2011). Conservation easement holders can be governmental bodies, but most often they are nonprofit land trusts (LTA 2011).

In this study we specifically follow two other studies in examining how various landowner attributes, behaviors, and land-use activities predict interest in conservation easements (Brenner et al. 2013, Farmer et al. 2016a). Brenner et al.'s (2013) early work on private landowners in the Finger Lakes Region of upstate New York utilized an efficient single page survey to relate independent predictor variables such as landowner attributes, land uses, and behaviors to interest in conservation easement adoption. Their resulting analysis determined that participation in environmental organizations, recreation, gathering of wild edibles, and land entitlement (amount of land owned) positively predicted interest in conservation easements. Following this in replication in southern Indiana's Brown County, Farmer et al. (2016a) found that landowners who (1) are relatively older (around 59 years), (2) are members of an environmental organization, (3) have land already enrolled in a private land conservation mechanism (in this case the Indiana Classified Forest and Wildlands Program or ICFWP), and (4) are not hunters or anglers were most likely to have an interest in placing a conservation easement. A key difference between these two studies was participation in the ICFWP, a program specific to Indiana that seeks to conserve private forest and other natural areas, albeit nonpermanently. Given the significance of participation in the ICFWP in predicting interest in conservation easements (Farmer et al. $2016 b$ ), we elected to explore interest in conservation easements

${ }^{1}$ Department of Recreation, Park, and Tourism Studies, Indiana University, ${ }^{2}$ School of Public Health, Indiana University, ${ }^{3}$ Ostrom Workshop, Indiana University, ${ }^{4}$ Ithaca College, ${ }^{5}$ School of Planning, University of Waterloo, ${ }^{6}$ Department of Epidemiology \& Biostatistics, Indiana University 
further by surveying landowners who had already enrolled property in the ICFWP. The importance of the ICFWP has been well documented, as Mayer and Tikka (2006:620) noted it as the oldest U.S. program to encourage "forest owners to manage or restore their forests to a "healthy" condition." The State of Indiana reports that $>15,463$ enrolled parcels total $>302,000$ ha that are enrolled in the program (State of Indiana 2014).

Based on the prominence of this private land conservation program in previous research and the researchers' recent published results, three specific questions guided the present work:

1. What are the differences between ICFWP participants who show interest in conservation easements and those who do not?

2. Within this group of temporary PLC participants, which variables best predict interest in permanent PLC through conservation easements?

- $\mathrm{H}_{1}$ : Individuals engaged in land uses that account for no monetary gain would be more apt to declare interest in or grant conservation easements.

- $\mathrm{H}_{2}$ : Individuals who are members of an environmental organization are more apt to have an interest in conservation easements.

3. How might outdoor recreation as an adult help explain private landowner interest in conservation easements?

- $\mathrm{H}_{3}$ : Individuals who more often visit natural areas for recreation would be more apt to show interest in conservation easements.

\section{Background literature}

Although conservation easements have existed in the United States since the late 19th century (Gustanski and Squires 2000), their popularity as a PLC mechanism began to increase in the 1980s with changes to the federal tax structure, which occurred following the Unified Conservation Easement Act (UCEA; Gustanski and Squires 2000). This coincided with a decline in governmental procurement of private land and a growth in land trusts (King and Fairfax 2006). In 2011, state and local land trusts nationwide held 3.57 million ha under conservation easements (LTA 2011). Fundamental to understanding the potential of land trusts in PLC is research on the factors that might predict and promote adoption of conservation easements among private landowners (Brenner et al. 2013, Drescher 2014, Farmer et al. 2015). Understanding how these factors figure into land conservation decisions could help land trusts and other conservation professionals relate and reach out to prospective easement donors.

In recent years, scholarship has uncovered a host of variables that contribute to private landowners' decisions to place conservation easements, including environmental values, financial incentives, land use activities, membership in environmental organizations, and participation in other PLC programs (Elconin and Luzadis 1998, Kabii and Horowitz 2006, Kilgore et al. 2007, Cross et al. 2011, Farmer et al. 2011a,b, 2016a, Brenner et al. 2013). Protecting the environment (Erickson et al. 2002) is another oft-cited nonmonetary benefit of land ownership that can motivate conservation behavior. Proenvironmental behavior can be influenced by environmental attitudes, beliefs, and values (Kaiser et al. 1999, Schultz et al. 2005, Farmer et al. 2011b). Many studies have supported the claim that environmental values are a key motivator for the adoption of conservation easements (Elconin and Luzadis 1998, Jacobson 2002, Ryan et al. 2003, Farmer et al. 2015). Brenner et al. (2013) found that being an active member of an environmental organization was a strong predictor of interest in adopting a conservation easement, as did Farmer et al. (2016a). Table 1 organizes and highlights variables discussed in this literature review and used to test interest in conservation easement placement.

Table 1. Variables used to evaluate and predict interest in conservation easements in accordance with the literature on previous conservation easement and related private land conservation scholarship.

\begin{tabular}{ll}
\hline \hline Variables & Citation \\
\hline Land use (LU): residency & $\begin{array}{l}\text { Rickenbach and Kittredge 2009, } \\
\text { Petrzelka et al. 2013 }\end{array}$ \\
LU: recreation (hiking/ATV & $\begin{array}{l}\text { Bliss 1989, Koontz 2001, Brenner et } \\
\text { al. 2013 } \\
\text { riding, etc.) }\end{array}$ \\
LU: hunting/fishing & Brenner et al. 2013 \\
LU: timber harvesting & Koontz 2001, Farmer et al. 2016b \\
LU: wild food gathering for & Robbins et al. 2008, Brenner et al. \\
personal consumption & 2013 \\
LU: wild food gathering for & Robbins et al. 2008, Brenner et al. \\
market sale & 2013 \\
LU: firewood harvesting & Koontz 2001 \\
Visitation to state park(s) & Wilson 1984, Bixler and James 2005 \\
Visitation to state forest(s) & Wilson 1984, Bixler and James 2005 \\
Visitation to national forest(s) & Wilson 1984, Bixler and James 2005 \\
Acreage owned & Farmer et al. 2016a, $b$ \\
Outdoor recreation - as youth & Bixler and James 2005, Farmer et al. \\
& 2011c \\
Outdoor recreation - as adult & Bliss 1989, Theodori et al. 1998 \\
Perception of landscape change & Brenner et al. 2013 \\
Env. organization membership & Brenner et al. 2013, Farmer et al. \\
& $2016 a$ \\
\hline
\end{tabular}

Central to the issue of PLC program participation is whether or not landowners depend on their land for their livelihood. Farmer et al. (2015) found that landowners who receive monetary benefits from their land were less likely than others to consider conservation easements without financial incentives. This finding has been supported in other studies where the most important motivators for placing conservation easements were financial incentives or land-based income (Kabii and Horwitz 2006, Cross et al. 2011). Conversely, some studies have reported that financial incentives did not influence conservation-based management decisions (Kilgore et al. 2007). In addition, Koontz (2001) found that respondents with lower incomes were more likely to use their land for financial return, i.e., harvesting timber or nonforest timber products for market sale, while respondents with higher incomes were more likely to engage in active protection, citing recreation and aesthetics as important benefits of land ownership. 
There is similar disagreement in the literature on the influence of recreational land use and conservation behavior, with some studies identifying recreational benefits as key drivers of conservation behavior (Bliss 1989, Koontz 2001, Brenner et al. 2013) and others finding it to be inconsequential (Bourke and Luloff 1994). Often, recreational benefits are cited in the context of nonmonetary benefits of land ownership and can include preserving forest land for hiking (Koontz 2001), wildlife viewing (Campbell and Kittredge 1996, Koontz 2001), and landscape aesthetics (Koontz 2001, Erickson et al. 2002, Ma et al. 2012).

Another important factor is residency. The sparse research on residency and participation in voluntary PLC programs suggests that individuals living on their land are more likely to participate in voluntary PLC programs than absentee landowners (Petrzelka et al. 2013). Additionally, resident landowners are more likely to engage in land protection (Rickenbach and Kittredge 2009), active land management (Kendra and Hull 2005, Finely and Kittredge 2006, Knoot et al. 2009), and governmental forest stewardship programs (Finley and Kittredge 2006).

Most of these studies focused on recreational activities on privately owned land itself, but few, if any, considered landowners' overall outdoor recreation pursuits as adults or youth. Brenner et al. (2013) and Farmer et al. (2016a) attempted to account for outdoor recreation in their research on interest in conservation easements by asking questions about visitation to nearby protected natural areas. Neither study found these variables to be significant predictors. However, links have been drawn between outdoor recreation with environmental socialization and significant life experiences in the context of PLC. Based on the early significant life experience work of Tanner (1980) and Chawla (1998), as well as the environmental socialization research of Bixler and James (2005), scholars have posited that early life experiences in nature that include unstructured free play and adult mentoring are common variables amongst individuals engaged in proenvironmental behaviors. Farmer et al. (2011c) found these experiences to have been present for many Indiana landowners who had opted for permanent land protection with conservation easements. Although much outdoor recreation research has focused on youth experiences, little is known about adult outdoor recreation pursuits and environmental behaviors, particularly in the realm of landowner decision making.

The majority of the aforementioned conservation easement studies were able to extract explanations for why people opted to place a conservation easement; however, only Brenner et al. (2013) and Farmer et al. (2016a) compared landowners who were interested versus those who were not interested. Accordingly, the current study builds on this work to further explore the linkage between participation in a nonpermanent PLC program (ICFWP) and interest in conservation easements as a permanent PLC mechanism.

\section{METHODS}

\section{Study area}

Today, Indiana's land cover is dominated by herbaceous species and nonwoody vegetation such as lawns, grasses, cropland, and pastureland. Within these land cover types, cropland is dominant, covering $65 \%$ of the state (Farmland Information Center 2014). Forests cover $19 \%$ of the state.
Indiana was $85-93 \%$ forested prior to European settlement in the early 19th century (Jackson 2004, Smith et al. 2004). By 1920, because of the harvesting and exportation of its valued hardwood timber, Indiana had reduced its canopy cover to approximately $6 \%$ (Nelson 1998). According to the state's first forester, Charles C. Deam, Indiana was overharvested because of its quality hardwoods and would be treeless by 1935 (Deam 1920) Consequently, Deam proposed and developed the Indiana Classified Forest Program (the precursor of ICFWP). The program and legislation "encouraged proper timber management and watershed protection on private forests. The incentive for landowners to enroll their lands in the program was a reduction in property taxes. Property taxes on qualifying land was determined by assessing the land at $\$ 1.00$ per acre then applying the county tax rate resulting in a $90 \%$ or more tax reduction" (Nelson 1998). This tax rate holds today.

Lands qualified to be enrolled in the ICFWP include those that total $4.05+$ ha of forest, wetland, shrubland, and/or grassland. Activities not allowed include: grazing of domestic livestock; buildings such as houses, barns, and homes; intentional burning unless written into the management plan; and areas for the growing of Christmas trees. Landowners must develop a land management plan with a state district forester, file annual reports, and allow inspection of the property every five years. Enrollment in the program can be discontinued at any time, but removing land from the program requires payment of a fee: seven-years of back taxes based on the current zoning rate of the county, plus an additional 10\% interest charge (Bennett et al. 1995). Land enrolled as of December 31, 2014, totaled 302,039 ha.

\section{Survey sample, instrument, and data collection}

This study is part of a larger international project comparing data from participants in state/provincial tax-incentivized conservation programs in Indiana, the United States and Ontario, Canada. The population of interest in this study includes a sample from approximately 10,000 Indiana landowners who have their property enrolled in the ICFWP. A stratified sample of 500 names/ addresses of these individuals was acquired from the Indiana Department of Forestry. Accordingly, the instrument was developed collaboratively with scholars from the University of Waterloo, Canada (see Appendix 1 for the Indiana-based questionnaire). This paper reports on specific components of the research based on results from Indiana.

Data analyzed for this paper were gathered from questions in Parts B, E, and F of the survey instrument (Appendix 1). Section $\mathrm{B}$ was focused on land stewardship, landscape features, and conservation management practices. Part $\mathrm{E}$ was based on Brenner et al.'s (2013) and Farmer et al.'s (2016a) instrument on land use, perception of landscape change, and interest in a conservation easement, as well as additional variables regarding participation in outdoor recreation as a youth and adult. Part F included demographic details.

The survey was administered on the basis of a modified Dillman Tailored Design Method (Dillman et al. 2009), which included the provisioning of a $\$ 2$ bill as a prepaid cash incentive. In the $U$. S., $\$ 2$ bills are rarely received in circulation so they are novel and, we hoped, intriguing enough to inspire a response. Questionnaires were sent to 500 sampled ICFWP participants. After 68 were returned for insufficient addresses 432 recipients remained. 
Mailing 1 included an informational letter alerting participants to the ensuing survey. Mailing 2 included the survey and the \$2 bill. Mailing 3 was a follow-up postcard reminder that we were still collecting data. Data from returned questionnaires were entered into a Qualtrics online survey to minimize input error while generating the dataset in a downloadable SPSS file.

\section{Survey data analyses}

Analysis took place in SPSS 21.0. First we created descriptive statistics for the demographic, land use, acreage, visitation to protected areas, outdoor recreation levels, and environmental organization membership variables based on the dichotomy of no interest versus some interest in a conservation easement. We then conducted Chi-square analyses on categorical variables and t-tests on the continuous variables to test for differences between the two groups. Pearson Chi-square tests were used to compare the percent of respondents showing interest in conservation easements and those not having an interest. Independent Samples T-tests were used to compare means between the "none" vs "some" interest groups on continuous measures (area owned, area in ICFWP, number of visits per year to protected areas, perceptions of landscape change, and outdoor recreation activity). Area owned, area in ICFWP, and number of visits per year to protected areas were all log-transformed before including in the T-tests to achieve normally distributed data. These analyses were used to answer our first research question.

To answer the second research question and to test hypotheses, we used a stepwise logistic regression model that included the seven land uses, visitation to three types of protected areas, and total acreage owned (Brenner et al. 2013). We also included total acreage enrolled in the ICFWP based on the outcomes of Farmer et al. $(2016 a, b)$, outdoor recreation activity levels as a youth (Bixler and James 2005) and as an adult (Bliss 1989), perception of landscape change (Brenner et al. 2013), membership in environmental organizations (Brenner et al. 2013, Farmer et al. 2016a), as well as four demographic variables: age, gender, educational attainment, and household income, all of which are well discussed as important variables in the conservation easement literature (Cross et al. 2011, Farmer et al. 2015). The dependent variable was a dichotomous indicator of whether individuals had placed a conservation easement or were interested in a conservation easement for their land (1), or were not interested and had not placed a conservation easement (0). Within this dichotomous dependent variable, we included those who had placed a conservation easement on their land in the same group as those who expressed interest in doing so. Although these two behaviors (stated interest and revealed behavior) are not equivalent, they both stand apart from having no interest, which in turn produced no revealed behavior. The stepwise regression model automatically removed variables that were insignificant. Finally, we used correlation analysis to explore the linkage of adult outdoor recreation activity level and conservation management activities, which seemed warranted based on results from the regression analysis.

The final research question, which sought to understand how might outdoor recreation as an adult help explain private landowner interest in conservation easements, was quantified by asking participants about their level of outdoor recreation as an adult. Participants were asked to rate their level of outdoor activity (examples given include: hiking, camping, boating, etc.) as an adult using a Likert scale ( 1 = inactive, 2 = somewhat inactive, $3=$ somewhat active, and $4=$ active). Both analyses ran for research questions 1 and 2 contributed to answering this research question. Additionally, we conducted correlation analysis between adult outdoor recreation level and 10 conservation management activities collected in section 2 of the questionnaire.

\section{RESULTS}

\section{Response rate and participant profile}

Of the 432 questionnaires sent, 308 (71\%) were returned. After removing incomplete questionnaires, 281 ( $65 \%$ of the original set) were suitable for analysis. Demographically, respondents were predominantly older (mean age 63 ), white $(100 \%)$, and male (81\%). Twenty percent had at minimum a bachelor's degree. In terms of livelihoods, $43 \%$ were employed full-time while $41 \%$ were retired. Seventy-three percent noted a 2013 household income of about $\$ 50,000 ; 29 \%$ listed household income above $\$ 100,000$. Over $45 \%$ of respondents described their property as a commercial farm, while $27 \%$ described it as a residential lot with surrounding land, $24 \%$ as a hobby farm, and $4 \%$ as a nonfarm rural business.

The median land area owned was 33.6 ha (mean 92.7 ha) and the median land area enrolled in the ICFWP was 17.4 ha (mean 31.9 ha). Of the respondents, $61 \%$ indicated that their land was dominated by forest cover, while $36 \%$ indicated a mixture of land covers. The vast majority $(90 \%)$ of respondents enrolled land in the ICFWP themselves, and 58\% knew someone else who participated in the ICFWP. The average landowner knew 3.8 others with land enrolled in the program. Almost a third of respondents reported that participation in the ICFWP by other landowners moderately or significantly affected their own participation in the program. See Table 2 for full demographic, land use, and behavioral descriptive results.

RQ1: What are the differences between ICFWP participants who show interest in conservation easements and those who do not? Over half $(51.2 \%)$ of our respondents had heard of conservation easements prior to the survey. One group of landowners included 34 who had granted conservation easements on their property and 77 who expressed interest in granting an easement $(\mathrm{n}=111)$. The other group included 131 landowners who expressed no interest. Table 3 compares these two groups on demographics, land entitlement, land use, and other independent variables.

Significant differences $(p<0.05)$ were detected for the variables of educational attainment, household income, visitation frequency to national forests, and outdoor recreation activity level as an adult between those with and without an interest in conservation easements. As educational attainment increased, so did the likelihood an individual would have an interest in a conservation easement. And those with income levels between $\$ 25,000$ to $\$ 50,000$ and $\$ 75,000$ to $\$ 150,000$ were more likely to have an interest in conservation easements than those with other income levels. Those who showed an interest in conservation easements reported visiting national forests more often, having a higher perception of landscape change, and having a higher outdoor recreation activity level than those with no interest. 
Table 2. Results of descriptive analyses and comparison tests between individuals with no interest and some interest in placing a conservation easement.

\begin{tabular}{|c|c|c|c|}
\hline Variable & Variable & $\begin{array}{l}\text { No Interest } \\
\mathrm{N}=131\end{array}$ & $\begin{array}{l}\text { Some Interest } \\
\qquad \mathrm{N}=111\end{array}$ \\
\hline Age & & 63.33 & 61.02 \\
\hline Gender & Female/Male & $55 \% / 50 \%$ & $45 \% / 50 \%$ \\
\hline \multirow[t]{4}{*}{ Employment Status } & Employed $>30 \mathrm{hrs} . /$ week & $53 \%$ & $47 \%$ \\
\hline & Employed $<30 \mathrm{hrs}$./week & $33 \%$ & $67 \%$ \\
\hline & Retired & $59 \%$ & $41 \%$ \\
\hline & Other & $67 \%$ & $33 \%$ \\
\hline \multirow[t]{4}{*}{ Educational Attainment*** } & No college & $23.66 \%$ & $26 \%$ \\
\hline & Some college / technical & $34.35 \%$ & $42 \%$ \\
\hline & Bachelor's degree & $22.90 \%$ & $42 \%$ \\
\hline & Prof. or graduate degree & $19.08 \%$ & $63 \%$ \\
\hline \multirow{7}{*}{ Household Income** } & $\$ 0-\$ 25,000$ & $9.92 \%$ & $24 \%$ \\
\hline & $\$ 25,000-\$ 50,000$ & $10.69 \%$ & $59 \%$ \\
\hline & $\$ 50,000-\$ 75,000$ & $26.72 \%$ & $31 \%$ \\
\hline & $\$ 75,000-\$ 100,000$ & $16.79 \%$ & $55 \%$ \\
\hline & $\$ 100,000-\$ 150,000$ & $9.16 \%$ & $57 \%$ \\
\hline & $\$ 150,000+$ & $16.03 \%$ & $38 \%$ \\
\hline & No response & $10.69 \%$ & $52 \%$ \\
\hline \multirow[t]{2}{*}{ Land Entitlement } & Hectares owned & $83.2(\operatorname{Mdn} 32.8)$ & $96.3(\operatorname{Mdn} 44.5)$ \\
\hline & ICFWP hectares & $28.5(\mathrm{Mdn} 16.6)$ & $32.3(\operatorname{Mdn} 30.4)$ \\
\hline \multicolumn{4}{|l|}{ Land Use } \\
\hline & Permanent residence for you and/or your family & $57.25 \%$ Yes & $63.96 \%$ Yes \\
\hline & Recreation (e.g., hiking, ATV use, etc.) & $77.86 \%$ Yes & $85.59 \%$ Yes \\
\hline & Hunting or fishing (by you or someone else) & $77.10 \%$ Yes & $75.68 \%$ Yes \\
\hline & Harvesting wild foods for personal consumption & $32.82 \%$ Yes & $45.05 \%$ Yes \\
\hline & Harvesting wild foods for market sale & $1.53 \% \mathrm{Yes}$ & $3.60 \%$ Yes \\
\hline & Firewood harvesting (outside of top removal) & $47.33 \%$ Yes & $54.05 \%$ Yes \\
\hline & Timber harvesting (by you or someone else) & $47.33 \%$ Yes & $38.74 \%$ Yes \\
\hline Visitation to Protected Area & State Forest & 1.21 & 3.12 \\
\hline \multirow[t]{2}{*}{ (visits per annum) } & State Park & 2.61 & 3.03 \\
\hline & National Forest*** & 0.67 & 1.68 \\
\hline \multicolumn{2}{|l|}{$\begin{array}{l}\text { Perception of county landscape change** } \\
(1=\text { Strongly Disagree }-5=\text { Strongly Agree })\end{array}$} & 3.48 & 3.88 \\
\hline \multirow{2}{*}{$\begin{array}{l}\text { Outdoor recreation activity level }(1=\text { very } \\
\text { inactive }-4=\text { very active })\end{array}$} & as a teenager & 3.50 & 3.52 \\
\hline & as an adult*** & 3.19 & 3.51 \\
\hline Member of Env. Org.*** & & $19.08 \%$ Yes & $44.14 \%$ Yes \\
\hline
\end{tabular}

$* p<0.1 ; * *<0.05 ; * * * p<0.01 ; * * * * p<0.001$

Table 3. Results of forward stepwise logistic regression on interest in conservation easement $(0=$ no interest; $1=$ some interest or already have easement).

\begin{tabular}{lc}
\hline \hline Variables & $\begin{array}{c}\mathrm{B}(\text { Odds } \\
\text { Ratio })\end{array}$ \\
\hline $\begin{array}{l}\text { Constant } \\
\text { Perception that landscape in county has changed }(1=\end{array}$ & $-3.127(\mathrm{NA})$ \\
$\begin{array}{l}\text { Strongly Disagree }-5=\text { Strongly Agree) } \\
\text { Outdoor recreation activity level as an adult }(1=\text { very }\end{array}$ & $0.57(1.76)^{* *}$ \\
inactive - $4=$ very active) & \\
Member of an environmental organization (Yes vs No) & $1.04(2.83)^{* *}$ \\
\hline$B=$ Beta parameter estimate from model; ${ }^{*} p<0.05 ; * * p<0.01$
\end{tabular}

RQ2: Within this group of temporary PLC participants, which variables best predict interest in permanent PLC through conservation easements?

To better understand which variables best predicted interest in a conservation easement we used a forward stepwise logistic regression procedure including independent variables in Tables 1 and 2 regressed on the dependent variable "interest in a conservation easement." This variable was coded as no interest in a conservation easement $=0$ and interest or placement of a conservation easement $=1$ (questionnaire Part E, Questions $4 \mathrm{~b}$ and $4 c)$. The model returned three significant $(\mathrm{p}<0.05)$ predictors (perceptions that landscape changed; outdoor recreation as an adult; membership in an environmental organization), presented in Table 4. As scores increased in these three variables, the likelihood of expressing interest in a conservation easement increased significantly, as represented by odds ratios $(\exp [B])$.

Odds ratios in this study can be interpreted as follows: for each unit increase in any independent variable, the odds of also expressing interest in a conservation easement increases by a multiplicative factor of that independent variable's odds ratio. For example, someone who "strongly agrees" with having perceived landscape change in the county has 1.23 times the odds of being interested in a conservation easement compared with someone who only "somewhat agrees" (Wald Chi-square[1] $=4.19, \mathrm{p}=$ 0.041). Similarly, someone who reports one unit higher in outdoor 
activity has 1.76 times the odds of showing interest in a conservation easement compared with someone who reporting one unit lower (Wald Chi-square[1] $=8.332, \mathrm{p}=0.004$ ). The most powerful predictor of interest in a conservation easement is being a member, donor, or participant in an organization that focuses on environmental issues. Those who reply "Yes" to supporting environmental organizations have 2.83 times the odds of showing interest in a conservation easement (Wald Chi-square[1] $=11.65$, $p=0.044)$. Because these predictor variables are entered into the logistic regression model simultaneously, each odds ratio reported here is adjusted to account for the other two variables in the model.

Table 4. Results of correlation analysis between conservation management strategies to adult outdoor recreation activity level (ordinal rank scale of $1=$ not planned; 2 = planned; $3=$ underway; $4=$ completed).

\begin{tabular}{lccc}
\hline \hline Conservation Mgmt. Strategy & Mean & $p$ value & $\begin{array}{c}\text { Correlation } \\
\text { Coefficient }\end{array}$ \\
\hline $\begin{array}{l}\text { Removal/control of invasive } \\
\text { species }\end{array}$ & 2.73 & 0.176 & 0.090 \\
Planting of native species & 2.36 & $0.061^{*}$ & 0.127 \\
Prescribed burning & 1.44 & $0.089^{*}$ & 0.116 \\
Removal of unhealthy trees & 2.39 & $0.049^{*}$ & 0.132 \\
Removal of unsafe trees & 2.14 & $0.071^{*}$ & 0.123 \\
Habitat improvement & 2.61 & $0.000^{* * * *}$ & 0.245 \\
Groundwater protection & 1.92 & 0.166 & 0.094 \\
Erosion control & 2.13 & $0.001^{* * *}$ & 0.223 \\
Monitoring environmental & 1.92 & 0.231 & 0.081 \\
conditions & & & \\
Allowing natural succession & 2.57 & $0.061^{*}$ & 0.126 \\
\hline$* p<0.1 ; * * *<0.01 ; * * * *<0.001$ & &
\end{tabular}

$* p<0.1 ;{ }^{* * *} p<0.01 ; * * * * p<0.001$

Those interested in conservation easements reported they were more active as adults in outdoor recreation than those with no interest in conservation easements. Specifically, 59\% of respondents interested in conservation easements indicated that they are very active in outdoor recreation, compared to $38 \%$ of respondents not interested in conservation easements.

We hypothesized that individuals engaged in land uses that account for no monetary gain would be more apt to declare interest in or grant conservation easements. Our regression results did not find this to be the case, rather, none of the land uses tested was a significant predictor of interest in a conservation easement. We also hypothesized that individuals who are members of an environmental organization are more apt to have an interest in conservation easements. Our results did support this hypothesis. Among landowners interested in a conservation easement, $44 \%$ belonged to an environmental organization, compared with $19 \%$ of those not interested in a conservation easement. Based on the regression results, belonging to an environmental organization increases the probability of conservation easement interest by $12 \%$.

RQ3: How might outdoor recreation as an adult help explain private landowner interest in conservation easements?

Finally, we hypothesized that individuals who more often visit natural areas for recreation would be more apt to show interest in conservation easements. The results of our survey showed a significant relationship of interest in conservation easements with visitation to national forests ( $\mathrm{p}<0.001)$, as well as activity level of outdoor recreation as an adult $(\mathrm{p}=0.001)$ but not with visitation to state parks or state forests. Multiple regression results in Table 3 highlight that adult outdoor recreation activity was a significant indicator of interest in a conservation easement $(\mathrm{p}<$ 0.01 ), whereas visitation to national forests was no longer significant after accounting for significance of outdoor recreation and membership in an environmental group.

To further explore this result, we compared adult outdoor recreation activity level with data on engagement in 10 conservation management activities given land management and eco-restoration activities are equated to a recreation activity and leisure experience according to Chen et al.'s (2013) supposition on horticultural activities. Results from the correlation analysis indicated that adult outdoor recreation activity level was significantly correlated with actions leading to habitat improvement and erosion control activities. The effects of each were marginal, which was expected given the indirect linkage. Several other conservation management activities were marginally correlated with the adult outdoor recreation activity level.

\section{DISCUSSION}

Perception of landscape change, outdoor recreation as an adult, and membership in an environmental organization were all found to be the most powerful predictors of whether or not landowners enrolled in temporary PLC programs (in this case the ICFWP) would show interest in pursuing a permanent conservation easement. Although these results are somewhat consistent with other literature on PLC participants (e.g., Brenner et al. 2013), the specificity of the results pertaining to outdoor recreation and landscape change perception make important contributions to the literature and the field of land conservation by better describing those landowners interested in conservation easements.

As in other studies (e.g., Brenner et al. 2013, Farmer et al. 2016a), membership in an environmental organization was found to be the strongest determinant of interest in conservation easements. Previous studies have also linked conservation behavior to environmental awareness (Zorondo-Rodríguez et al. 2014) and environmental values (Elconin and Luzadis 1998, Jacobson 2002, Ryan et al. 2003, Farmer et al. 2015). Perhaps, in our case, environmental awareness and environmental values are manifested through membership in environmental organizations.

Still more revealing are the roles of adult outdoor recreation activity and perception of landscape change. Interestingly, the variable "recreational use," explicitly characterized as an on-site land use, was not found to be significantly related to conservation easement interest (in contrast with Brenner et al. 2013). However, adult outdoor recreation activities writ large were significant. Although the literature on recreation's relationship to conservation behavior has yielded mixed results, our study suggests that engagement in outdoor recreation experiences anywhere is positively related to interest in granting a conservation easement on one's own property. Our results support the early work on outdoor recreation and proenvironmental behavior of Dunlap and Heffernan (1975), who found outdoor recreationists to report more engagement in proenvironmental behaviors than the general public. The work of Theodori and 
others (1998) further specified the relationships between specific outdoor recreation and proenvironmental behavior. For example, hunting and off-road vehicle use were not aligned with proenvironmental behavior, while lower-impact, nonextractive activities like picnicking, camping, hiking/backpacking, and mountain biking were aligned with proenvironmental behavior. Conversely, our results linking outdoor recreation to environmental behavior interest/intention contradict subsequent findings of Nisbet et al. (2009) and Teisl and O'Brien (2003).

Landowners most interested in conservation easements were active outdoor recreationists who visited national forests significantly more often than others. One possible explanation for this outcome is that when compared to state parks and state forests, the Hoosier National Forest is less developed, with fewer amenities, and likely draws a different type of recreationist. Our finding also raises a question: To what extent do these landowners who report engagement in outdoor recreation do so on their own property? Bliss (1989) reported that recreation was a prime objective of private forest landowners. This study also reported that recreating on their own land was a meaningful family activity. Further, managing the land itself was a form of recreation for many landowners. In Butler and Leatherby's (2004) survey of family forest owners, nearly half of respondents reported that an important reason for owning forestland was hunting or other recreation.

Hunting was not a strong predictor of interest in permanent land conservation in our study. Instead, our study suggests an alternative explanation involving land management activities as a form of recreation and leisure. Correlation results (Table 4) show a relationship between conservation management activities and adult outdoor recreation. One possible explanation is that landowners are engaging in a sort of "functional leisure." Based on Stebbin's definition that leisure is an "uncoerced activity engaged in during free time, which people want to do and, in either a satisfying or a fulfilling way (or both), use their abilities and resources to succeed at" (Stebbins 2008:4), functional leisure would comprise those uncoerced activities that people engage in that result in an end product or accomplishment. Land management and conservation activities might fit this definition. Indeed, most of the conservation management activities from our survey would not be considered mandatory requisites for owning the land; rather, landowners might be internally, if at all, compelled to engage in these activities. As found by (Farmer et al. 2016b) analysis of land use activities (environmental, residential, or financial) in relation to conservation management activities, those using land for more environmental protection or residential purposes were more apt to engage in and complete conservation management activities. In essence, we propose these landowners are engaging in productive, or functional leisure. This functional leisure hypothesis is consistent with research carried out by Brenner et al. (2013), which suggested that landowners who actively use, or work, their land (albeit not for income) are significantly more likely to support permanent land conservation through conservation easements.

Residency on ICFWP land, surprisingly, was not a significant predictor of conservation easement interest in our study. The importance of residential status was particularly intriguing given that it has only recently been acknowledged in the literature.
Petrzelka et al. (2013), for example, found that individuals living on their land were more likely to participate in voluntary conservation programs than those with single use parcels not containing a residence. Meanwhile, absentee forestland owners have been found to be less motivated, interested, or engaged in the management and protection of their property (Kendra and Hull 2005, Finely and Kittredge 2006, Rickenbach and Kittredge 2009, Knoot et al. 2009). The relationships between permanent and seasonal residency, absenteeism, and voluntary land conservation warrant more research in the future.

\section{PROFESSIONAL IMPLICATIONS, LIMITATIONS, AND FUTURE DIRECTIONS}

Our results have a number of potentially important implications for policy, practice, and future research. Our demonstration that interest in permanent private land conservation depends significantly on other widespread activities such as support for environmental organizations and outdoor recreation suggests great potential to "mainstream" this conservation mechanism.

Land conservation organizations, which typically broker and hold conservation easements, could partner with state agencies responsible for managing public lands by using state land conservation program rosters to identify landowners with high potential for granting conservation easements. For example, a statewide or local land trust could work with the state's department/division of natural resources to identify and communicate with landowners already involved in voluntary PLC programs such as the ICFWP. Another promising approach would be for land conservation organizations to work with local environmental organizations and identify their landowning members who might also be potential conservation easement grantors. A precedent for such a collaboration is the Virginia Outdoors Foundation, which has protected land at large spatial scales (over 303,514 ha throughout the commonwealth) via strong working relationships with nongovernmental organizations like local land trusts (Virginia Outdoors Foundation 2016).

Permanent private-land conservation easement programs could also help achieve conservation goals over long temporal scales via combination with nonpermanent voluntary conservation programs, such as the ICFWP. Landowners who initially enrolled land in a nonpermanent mechanism like the ICFWP could later be approached to consider permanent protection mechanisms such as conservation easements. Thus, conservation easement programs, if developed as mainstream opportunities for environmentally minded private landowners could play a pivotal role in an integrated effort to achieve large-landscape conservation goals over the short, medium, and long terms (Trombulak and Baldwin 2010).

Our study has a number of limitations that should be considered with the interpretation of the data and for future use of the survey methodology. The present study was limited to only one program in Indiana in which respondents were overwhelming older, white males. Future studies should continue to strive for samples that represent landowning populations. In this regard, studies on more demographically and geographically diverse landowners should be undertaken to determine if they may yield similar or different results. Generalizations about landowner decision making and behavior vis-à-vis permanent voluntary land conservation will depend on broader representation of the landowning population nationwide. 
The instrument used in our study, developed by Brenner et al. (2013), lacks the breadth and depth necessary for fine-grained and nuanced data collection on landowner motivations. Multipleitem factors from a more detailed instrument would enhance our capacity for measuring multidimensional items embedded within land use. Response and nonresponse bias are always concerns in survey research such as this. We were unable to account for nonresponse bias; therefore we contend that the results are representative of respondents to this survey and others like them. Finally, our choice to lump those that had placed a conservation easement with those that indicated an interest in doing so runs the risk of conflating stated and revealed preferences. More research should more specifically tease out differences between those who show interest in conservation easements, those who actually grant them, and those who show no interest. Future studies should specifically solicit data from individuals who had considered a conservation easement but declined to grant one. Unfortunately, landowners such as these are not identifiable in public records, so they must be approached through survey research, which is subject to the biases discussed above. One way to control for the confounding factor of easement awareness and knowledge is to provide more in-depth educational material about conservation easements prior to administering a survey.

Future research should seek to expand and refine the Brenner et al. (2013) instrument in a manner that does not compromise its efficiency while allowing for more robust analysis and more nuanced interpretation. One notable gap is questions that would illustrate how recreational experiences on one's own land influence proenvironment values and land-conservation behaviors. Especially promising is work that could provide a more fine-grained understanding of on-site recreational activities, especially land management-as-leisure, or what we call productive leisure or functional leisure. Such work could shed important, much-needed light on the issues for researchers in their endeavor to understand conservation decision making on private lands.

Responses to this article can be read online at: http://www.ecologyandsociety.org/issues/responses. $\mathrm{php} / 8515$

\section{Acknowledgments:}

We thank Indiana University's Dept. of Recreation, Park, and Tourism Studies for funding in support of this research. We also thank Dr. Burnell C. Fischer, Mr. Jay Whitacre, and Mr. Justin Wolfe for their contributions to this project. Finally, we thank Indiana's Division of Forestry for assisting us in our contact with landowners.

\section{LITERATURE CITED}

Bennett, J., J. McElfish, and A. Bale. 1995. Indiana's biological diversity: strategies and tools for conservation. Environmental Law Institute, Washington, D.C., USA.

Bixler, R., and J. James. 2005. Environmental socialization: the critical peripheral? Pages 15-30 in W. L. Filho, editors. Handbook of Sustainability Research. Peter Lang, Berlin, Germany.
Bliss, N. B. 1989. A national natural resource data base: techniques for linking the major land resource area map, the 1982 national resources inventory and the soils interpretations record data bases in a geographic information system. Eros Data Center, Sioux Falls, South Dakota, USA.

Bourke, L., and A. E. Luloff. 1994. Attitudes toward the management of nonindustrial private forest land. Society \& Natural Resources 7:445-457. http://dx.doi.org/10.1080/0894192$\underline{9409380880}$

Brenner, J. C., S. Lavallato, M. Cherry, and E. Hileman. 2013. Land use determines interest in conservation easement among private landowners. Land Use Policy 35:24-32. http://dx.doi. org/10.1016/j.landusepol.2013.03.006

Butchart, S. H. M., M. Walpole, B. Collen, A. van Strien, J. P. W. Scharlemann, R. E. A. Almond, J. E. M. Baillie, B. Bomhard, C. Brown, J. Bruno, et al. 2010. Global biodiversity: indicators of recent declines. Science 328:1164-1168. http://dx.doi.org/10.1126/ science. 1187512

Butler, B. J., and E. C. Leatherby. 2004. America's family forest owners. Journal of Forestry 102(7):4-14.

Byrd, K. B., L. E. Flint, P. Alvarez, C. F. Casey, B. M. Sleeter, C. E. Soulard, A. L. Flint, and T. L. Sohl. 2015. Integrated climate and land use change scenarios for California rangeland ecosystem services: wildlife habitat, soil carbon, and water supply. Landscape Ecology 30:729-750. http://dx.doi.org/10.1007/s10980-015-0159-7

Campbell, S. M. and D. B. Kittredge. 1996. Ecosystem-based management on multiple NIPF ownerships. Journal of Forestry 94(2):24-29.

Chawla, L. 1998. Significant life experiences revisited: a review of research on sources of environmental sensitivity. Environmental Education Research 4(4):369-382. http://dx.doi.org/10.1080/135$\underline{0462980040402}$

Chen, H., H. Tu, and C. Ho. 2013. Understanding biophilia leisure as facilitating well-being and the environment: an examination of participants' attitudes toward horticultural activity. Leisure Sciences 35(4):301-319. http://dx.doi. org/10.1080/01490400.2013.797323

Cross, J. E., C. M. Keske, M. G. Lacy, D. L. K. Hoag, and C. T. Bastian. 2011. Adoption of conservation easements among agricultural landowners in Colorado and Wyoming: the role of economic dependence and sense of place. Landscape and Urban Planning 101(1):75-83. http://dx.doi.org/10.1016/j. landurbplan.2011.01.005

Deam, C. 1920. The forests of Indiana, past, present, and future. Indiana Department of Conservation. One hundred years of Indiana's resources. Fort Wayne Printing Company, Fort Wayne, Indiana.

Dillman, D. A., J. D. Smyth, and L. M. Christian. 2009. Internet, mail, and mixed-mode surveys: the tailored design method. Third edition. Wiley, Hoboken, New Jersey, USA.

Drescher, M. 2014. What is it like to take care of the land? Toward an understanding of private land conservation. Rural Society 23 (2):117-132. http://dx.doi.org/10.5172/rsj.2014.23.2.117 
Dunlap, R. E., and R. B. Heffernan. 1975. Outdoor recreation and environmental concern: an empirical examination. Rural Sociology 40:18-30.

Elconin, P., and P. Luzadis. 1998. Landowner satisfaction with conservation easements. Wild Earth 8(Summer):49-51.

Erickson, D. L., R. L. Ryan, and R. De Young. 2002. Woodlots in the rural landscape: landowner motivations and management attitudes in a Michigan (USA) case study. Landscape and Urban Planning 58(2-4):101-112. http://dx.doi.org/10.1016/S0169-2046 (01)00213-4

Farmer, J. R., C. Chancellor, J. Brenner, J. Whitacre, and E. Knackmuhs. 2016a. To ease or not to ease: interest in conservation easements among landowners in Brown County, Indiana. Professional Geographer 68(3):1-11. http://dx.doi. org/10.1080/00330124.2015.1129910

Farmer, J. R., C. Chancellor, and B. C. Fischer. $2011 b$. Motivations for using conservation easements as a land protection mechanism: a mixed methods analysis. Natural Areas Journal 31 (1):80-87. http://dx.doi.org/10.3375/043.031.0109

Farmer, J. R., C. Chancellor, and B. C. Fischer. 2011c. Space to romp and roam and how it may promote land conservation. Natural Areas Journal 31(4):340-348. http://dx.doi. org/10.3375/043.031.0404

Farmer, J. R., D. Knapp, V. J. Meretsky, C. Chancellor, and B. C. Fischer. 2011a. Motivations influencing the adoption of conservation easements. Conservation Biology 25:827-834. http:// dx.doi.org/10.1111/j.1523-1739.2011.01686.x

Farmer, J. R., Z. Ma, M. Drescher, E. Knackmuhs, and S. L. Dickinson. 2016b. Private landowners, voluntary conservation programs, and implementation of conservation friendly land management practices. Conservation Letters. http://dx.doi. org/10.1111/conl.12241

Farmer, J. R., V. Meretsky, D. Knapp, C. Chancellor, and B. C. Fischer. 2015. Why agree to a conservation easement? Understanding the decision of conservation easement granting. Landscape and Urban Planning 138:11-19. http://dx.doi. org/10.1016/j.landurbplan.2015.01.005

Farmland Information Center. 2014. Indiana statistics. Farmland Information Center, United States Department of Agriculture, Washington, D.C., USA. [online] URL: http://www.farmlandinfo. org/statistics/Indiana

Finley, A. O., and D. B. Kittredge. 2006. Thoreau, Muir, and Jane Doe: different types of private forest owners need different kinds of forest management. Northern Journal of Applied Forestry 23 (1):27-34. [online] URL: http://harvardforest.fas.harvard.edu/ sites/harvardforest.fas.harvard.edu/files/publications/pdfs/ Finley_NorthAppFor_2006.pdf

Gustanski, J. A., and R. H. Squires, editors. 2000. Protecting the land: conservation easements past, present, and future. Island Press, Washington, D.C., USA.

Jackson, M. T. 2004. 101 Trees of Indiana: a field guide. Indiana University Press, Bloomington, Indiana, USA.

Jacobson, M. G. 2002. Factors affecting private forest landowner interest in ecosystem management: linking spatial and survey data. Environmental Management 30:577-583. http://dx.doi. org/10.1007/s00267-002-2605-y

Kabii, T., and P. Horwitz. 2006. A review of landholder motivations and determinants for participation in conservation covenanting programmes. Environmental Conservation 33:11-20. http://dx.doi.org/10.1017/S0376892906002761

Kaiser, F. G., S. Wölfing, and U. Fuhrer. 1999. Environmental attitude and ecological behavior. Journal of Environmental Psychology 19:1-19. http://dx.doi.org/10.1006/jevp.1998.0107

Kendra, A., and B. R. Hull. 2005. Motivations and behaviors of new forest owners in Virginia. Forest Science 51(2):142-154.

Kilgore, M. A., J. L. Greene, M. G. Jacobson, T. J. Straka, and S. E. Daniels. 2007. Influence of financial incentive programs in promoting sustainable forestry on the national's family forests. Journal of Forestry 105(4):184-191.

King, M. A., and S. K. Fairfax. 2006. Public accountability and conservation easements: learning from the Uniform Conservation Easement Act debates. Natural Resources 46:65-129.

Knoot, T. G., L. A. Schulte, N. Grudens-Schuck, and M. Rickenbach. 2009. The changing social landscape in the Midwest: a boon for forestry and bust for oak? Journal of Forestry 107:260-266.

Koontz, T. M. 2001. Money talks? But to whom? Financial versus nonmonetary motivations in land use decisions. Society \& Natural Resources 14:51-65. http://dx.doi.org/10.1080/08941920117246

Land Trust Alliance. 2011. The 2010 National Land Trust census report: a look at voluntary land conservation in America. Land Trust Alliance, Washington, D.C., USA. [online] URL: http://s3. amazonaws.com/landtrustalliance.org/page/files/2010LandTrustCensus. pdf

Lee, J. W. 2005. Foreword. Page ii in Millennium Ecosystem Assessment. Ecosystems and human well-being: health synthesis. World Health Organization, Geneva, Switzerland. [online] URL: http://www.who.int/globalchange/ecosystems/ecosystems05/en/index. $\underline{\mathrm{html}}$

Ma, Z., B. J. Butler, D. B. Kittredge, and P. Catanzaro. 2012. Factors associated with landowner involvement in forest conservation programs in the U.S.: implications for policy design and outreach. Land Use Policy 29(1):53-61. http://dx.doi. org/10.1016/j.landusepol.2011.05.004

Mayer, A. L., and P. M. Tikka. 2006. Biodiversity conservation incentive programs for privately owned forests. Environmental Science \& Policy 9:614-625. $\underline{\text { http://dx.doi.org/10.1016/j. }}$ envsci.2006.07.004

Nelson, J. 1998. Indiana's forests: past, present, \& future. Indiana Woodland Steward 7:3. [online] URL: http://woodlandsteward. squarespace.com/storage/past-issues/indiana $\% 27 \mathrm{~s} \% 20$ forest.htm

Nisbet, E. K., J. M. Zelenski, and S. A. Murphy. 2009. The nature relatedness scale: linking individuals' connection with nature to environmental concern and behavior. Environment and Behavior 41:715-740. http://dx.doi.org/10.1177/0013916508318748

Norton, D. A. 2000. Conservation biology and private land: shifting the focus. Conservation Biology 14:1221-1223. http://dx. doi.org/10.1046/j.1523-1739.2000.01451.x 
Petrzelka, P., Z. Ma, and S. Malin. 2013. The elephant in the room: absentee landowner issues in conservation and land management. Land Use Policy 30:157-166. http://dx.doi. org/10.1016/j.landusepol.2012.03.015

Rickenbach, M., and D. B. Kittredge. 2009. Time and distance: comparing motivations among forest landowners in New England, USA. Small-scale Forestry 8:95-108. http://dx.doi. org/10.1007/s11842-008-9071-1

Robbins, P., M. Emery, and J. L. Rice. 2008. Gathering in Thoreau's backyard: nontimberforest product harvesting as practice. Area 40(2):265-277. http://dx.doi.org/10.1111/ j.1475-4762.2008.00794.x

Ryan, R. L., D. L. Erickson, and R. De Young. 2003. Farmers' motivations for adopting conservation practices along riparian zones in a Midwestern agricultural watershed. Journal of Environmental Planning and Management 46(1):19-37.

Schultz, P. W., V. V. Gouveia, L. D. Cameran, G. Tankha, P. Schmuch, and M. Franěk. 2005. Values and their relationship to environmental concern and conservation behavior. Journal of Cross-Cultural Psychology 36:457-475. http://dx.doi. org/10.1177/0022022105275962

Seto, K. C., B. Güneralp, and L. R. Hutyra. 2012. Global forecasts of urban expansion to 2030 and direct impacts on biodiversity and carbon pools. Proceedings of the National Academy of Sciences 109(40):16083-16088. http://dx.doi.org/10.1073/pnas.1211658109

Smith, W. B., P. D. Miles, J. S. Vissage, S. A. Pugh. 2004. Forest resources of the United States, 2002. General technical report NC-241. U.S. Forest Service, North Central Research Station, St. Paul, Minnesota, USA. [online] URL: http://www.nrs.fs.fed.us/ pubs/1987

State of Indiana, Department of Natural Resources. 2014. Indiana Classified Forest \& Wildlands Program: 2014 Program Summary. IDNR, Indianapolis, Indiana. [online] URL: $\underline{\text { https:// }}$ secure.in.gov/dnr/forestry/files/fo-classified_forest_and_wildland_ program summary.pdf

Stebbins, R. 2008. A perspective for our time: serious leisure. Transaction, New Brunswick, New Jersey, USA.

Suarez-Rubio, M., P. Leimgruber, and S. C. Renner. 2011. Influence of exurban development on bird species richness and diversity. Journal of Ornithology 152:461-471. http://dx.doi. org/10.1007/s10336-010-0605-X

Tanner, T. 1980. Significant life experiences: a new research area in environmental education. Journal of Environmental Education 11(4):20-24. http://dx.doi.org/10.1080/00958964.1980.9941386

Teisl, M. F., and K. O'Brien. 2003. Who cares and who acts? Outdoor recreationists exhibit different levels of environmental concern and behavior. Environment and Behavior 35:506-522. http://dx.doi.org/ 10.1177/0013916503035004004

Theodori, G. L., A. E. Luloff, and F. K. Willits. 1998. The association of outdoor recreation and environmental concern: reexamining the Dunlap-Heffernan Thesis. Rural Sociology 63 (1):94-108. http://dx.doi.org/10.1111/j.1549-0831.1998.tb00666. $\underline{\mathrm{X}}$
Trombulak, S. C., and R. F. Baldwin, editors. 2010. Landscapescale conservation planning. Springer, Dordrecht, The Netherlands. http://dx.doi.org/10.1007/978-90-481-9575-6

United States Forest Service. 2001. U.S. forest facts and historical trends. [online] URL: http://www.fia.fs.fed.us/library/brochures/ docs/2000/ForestFactsMetric.pdf

Van Asselen, S., P. H. Verburg, J. E. Vermaat, and J. H. Janse. 2013. Drivers of wetland conversion: a global meta-analysis. PLoS ONE 8(11):e81292. http://dx.doi.org/10.1371/journal. pone.0081292

Virginia Outdoors Foundation. 2016. How we work. Virginia Outdoors Foundation, Warrenton, Virginia. [online] URL: $\underline{\text { http:// }}$ www.virginiaoutdoorsfoundation.org/protect/

Wilson, E. O. 1984. Biophilia. Harvard University Press, Cambridge, Massachusetts, USA.

Zorondo-Rodríguez, F., V. Reyes-García, and J. A. Simonetti. 2014. Conservation of biodiversity in private lands: are Chilean landowners willing to keep threatened species in their lands? Revista Chilena de Historia Natural 87:1-8. [online] URL: http:// www.revchilhistnat.com/content/87/1/4 
Appendix 1. Survey instrument.

\section{Part A: Participation in the Indiana Classified Forest and Wildlands Program (ICFWP)}

1. What year was your land first enrolled in the ICFWP?
A. Did you enroll the land in the ICFWP or was it enrolled when you obtained ownership of it?

$$
\begin{aligned}
& \square \quad \text { I enrolled the land in the ICFWP. } \\
& \square \quad \text { It was already enrolled when I obtained ownership of it. }
\end{aligned}
$$

B. Is your land still enrolled in the ICFWP?

$$
\begin{aligned}
& \square \quad \text { Yes } \\
& \square \quad \text { No } \\
& \text { If not, what year did you remove the land from the ICFWP? }
\end{aligned}
$$

2. Which of the following best describes your involvement in the ICFWP?

$\square$ Participant in the ICFWP

$\square$ Formerly a participant in ICFWP

$\square$ Never a participant in ICFWP (Please skip ahead to Section E on page 5)

3. In terms of eligibility for the ICFWP, which of the following best describes your property?
$\square$ Minimum of 10 acres of forest
$\square$ Minimum of 10 acres of grassland
$\square$ Minimum of 10 acres of wetland
$\square$ Mixture of land cover types; minimum
$\square$ Minimum of 10 acres of shrubland of 10 acres

4. How did you first learn about the ICFWP programs?

5. Do you know other landowners who participate in the ICFWP?

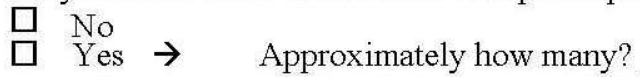

[IF Yes 3 5a. To what extent would you say the participation of other landowners influenced your decision to participate?

\begin{tabular}{|l|l|l|l|}
\hline Not at all & Minimally & Moderately & Significantly \\
\hline & & & \\
\hline
\end{tabular}

6. Which of the following best describes your property?
$\square$ Commercial farm, operated by you
Non-farm, rural business
$\square$ Commercial farm, leased or rented to
$\square$ Residential lot with surrounding lands another operator

$\square$ Hobby farm

7. How many totals acres of land do you own? (acres)

8. How many acres of land do you own that is enrolled in the ICFWP? (acres)

8a. How many separate parcels of land do you own that are enrolled in the ICFWP?

9. Please check all of the following features that your ICFWP enrolled property includes:
$\square$ Woodlands
$\square$ Natural grasslands
$\square$ Wetlands
$\square$ Streams / creeks

$\square \quad$ Natural lakes / ponds

$\square$ Man-made / dug lakes / ponds

$\square$ Other features: 


\section{Part B: Land Stewardship}

1. In your opinion, what term best describes the biodiversity found on your property enrolled in the ICFWP?

$\square$ Outstanding

$\square$ Good

$\square$ Fair

$\square$ Poor

2. Which of the following statements do you feel best describe the current status of the biodiversity on your ICFWP enrolled property?

$\square$ Overall the biodiversity of this property is improving

$\square$ On balance the biodiversity of this property is remaining about the same

$\square$ The general state of biodiversity on this property is declining

3. In terms of reasons for owning the land enrolled in the ICFWP, how important are the following reasons?

\begin{tabular}{|l|l|l|l|l|l|l|}
\hline \multicolumn{1}{|c|}{ Land Features } & $\begin{array}{c}\text { Very } \\
\text { important }\end{array}$ & Important & $\begin{array}{c}\text { Moderately } \\
\text { important }\end{array}$ & $\begin{array}{c}\text { Of little } \\
\text { importance }\end{array}$ & $\begin{array}{c}\text { Not } \\
\text { important }\end{array}$ & $\begin{array}{c}\text { Not } \\
\text { applicable }\end{array}$ \\
\hline To enjoy beauty or scenery & & & & & & \\
\hline To protect nature or biological diversity & & & & & & \\
\hline To protect water resources & & & & & & \\
\hline To protect or improve wildlife habitat & & & & & & \\
\hline For land investment & & & & & & \\
\hline It is part of my primary residence land & & & & & & \\
\hline Is part of my cabin or vacation home site & & & & & & \\
\hline Is part of my working farm or ranch & & & & & & \\
\hline For privacy & & & & & & \\
\hline To raise my family & & & & & & \\
\hline To pass land on to my heirs & & & & & \\
\hline For firewood & & & & & & \\
\hline For timber products, such as logs/pulpwood & & & & & & \\
\hline For nontimber products, such as nuts/syrup & & & & & & \\
\hline For hunting & & & & & & \\
\hline For recreation, other than hunting & & & & & & \\
\hline Other: & & & & & & \\
\hline
\end{tabular}

4. In terms of ecological management practices for this property, please indicate which of the following has been undertaken or is planned:

\begin{tabular}{|l|l|l|l|l|l|}
\hline \multicolumn{1}{|c|}{ Action/Activity } & Completed & Underway & Planned & $\begin{array}{c}\text { Not } \\
\text { Planned }\end{array}$ & $\begin{array}{c}\text { N/A @ this } \\
\text { Property }\end{array}$ \\
\hline Removal/control of invasive species & & & & & \\
\hline Planting of native species & & & & & \\
\hline Prescribed burns & & & & & \\
\hline Removal of unhealthy trees & & & & & \\
\hline Removal of unsafe trees & & & & & \\
\hline Improvements to wildlife habitat & & & & & \\
\hline Groundwater protection & & & & & \\
\hline Erosion control & & & & & \\
\hline Monitoring environmental conditions & & & & & \\
\hline Allowing natural succession & & & & & \\
\hline Other: & & & & & \\
\hline
\end{tabular}




\section{Part C: The ICFWP}

1. Overall, how would you rate the level of influence that the ICFWP has on the conservation of private lands in Indiana? (please select one answer)
$\square$ Not at all influential
$\square$ Slightly influential
$\square \quad$ Very influential
$\square$ Somewhat influential
$\square \quad$ Extremely influential
$\square$ Don't know

2. To what extent do you feel the following environmental issues are problems in Indiana?

\begin{tabular}{|l|l|l|l|l|l|}
\hline \multicolumn{1}{|c|}{ Issue } & $\begin{array}{c}\text { Serious } \\
\text { Problem }\end{array}$ & $\begin{array}{c}\text { Moderate } \\
\text { Problem }\end{array}$ & $\begin{array}{c}\text { Slight } \\
\text { Problem }\end{array}$ & $\begin{array}{c}\text { Probably not } \\
\text { a Problem }\end{array}$ & $\begin{array}{c}\text { Definitely } \\
\text { not a } \\
\text { Problem }\end{array}$ \\
\hline Damage to natural heritage & & & & & \\
\hline Loss of biodiversity & & & & & \\
\hline Threats to endangered species & & & & & \\
\hline Loss of quality woodlands & & & & & \\
\hline Loss of greenspace & & & & & \\
\hline $\begin{array}{l}\text { Spread of invasive species in } \\
\text { forest ecosystems }\end{array}$ & & & & & \\
\hline Threats to water quality & & & & & \\
\hline $\begin{array}{l}\text { Spread of invasive species in } \\
\text { freshwater ecosystems }\end{array}$ & & & & & \\
\hline
\end{tabular}

3. To what extent do you feel government programs like the ICFWP are necessary for achieving the following environmental goals?

\begin{tabular}{|l|l|l|l|l|}
\hline \multicolumn{1}{|c|}{ Environmental Goal } & $\begin{array}{c}\text { Very } \\
\text { Unnecessary }\end{array}$ & Unnecessary & Necessary & $\begin{array}{c}\text { Very } \\
\text { Necessary }\end{array}$ \\
\hline Protecting natural heritage and biodiversity & & & & \\
\hline Helping to preserve representative ecosystems & & & & \\
\hline Protecting endangered species & & & & \\
\hline Maintaining habitat & & & & \\
\hline Preserving woodlands & & & & \\
\hline Encouraging woodland management & & & & \\
\hline Preventing incompatible uses of greenspace & & & & \\
\hline Promoting natural heritage conservation & & & & \\
\hline Protecting water quality & & & & \\
\hline
\end{tabular}

4. In relation to the same set of environmental goals, how would you rate the effectiveness of the ICFWP?

\begin{tabular}{|l|l|l|l|l|l|}
\hline \multicolumn{1}{|c|}{ Environmental Goal } & $\begin{array}{c}\text { Very } \\
\text { Ineffective }\end{array}$ & Ineffective & Effective & $\begin{array}{c}\text { Very } \\
\text { Effective }\end{array}$ & $\begin{array}{c}\text { Don't } \\
\text { Know }\end{array}$ \\
\hline Protecting natural heritage and biodiversity & & & & & \\
\hline Helping to preserve representative ecosystems & & & & & \\
\hline Protecting endangered species & & & & & \\
\hline Maintaining habitat & & & & & \\
\hline Preserving woodlands & & & & & \\
\hline Encouraging woodland management & & & & & \\
\hline Preventing incompatible uses of greenspace & & & & & \\
\hline Promoting natural heritage conservation & & & & & \\
\hline Protecting water quality & & & & \\
\hline
\end{tabular}


5. Based on your experience, please rate the ICFWP in relation to the following criteria:

\begin{tabular}{|l|l|l|l|l|l|}
\hline \multicolumn{1}{|c|}{ Criteria } & Excellent & Good & Fair & Poor & Don't Know \\
\hline Overall program design & & & & & \\
\hline $\begin{array}{l}\text { Quality of information provided to } \\
\text { landowners }\end{array}$ & & & & & \\
\hline Timely response to questions you posed & & & & & \\
\hline $\begin{array}{l}\text { Technical advice provided to landowners } \\
\text { from professional foresters }\end{array}$ & & & & & \\
\hline $\begin{array}{l}\text { Support for developing a forest/land } \\
\text { management plan }\end{array}$ & & & & & \\
\hline Other: & & & & & \\
\hline
\end{tabular}

6. Please indicate whether you agree or disagree with each of the following statements:

\begin{tabular}{|c|c|c|c|c|}
\hline Statement & $\begin{array}{l}\text { Definitely } \\
\text { Agree }\end{array}$ & $\begin{array}{l}\text { Somewhat } \\
\text { Agree }\end{array}$ & $\begin{array}{l}\text { Somewhat } \\
\text { Disagree }\end{array}$ & $\begin{array}{l}\text { Definitely } \\
\text { Disagree }\end{array}$ \\
\hline \multicolumn{5}{|l|}{$\begin{array}{l}\text { The property tax reduction provided by the ICFWP doesn't } \\
\text { make the program worthwhile }\end{array}$} \\
\hline \multicolumn{5}{|l|}{$\begin{array}{l}\text { The ICFWP is a major reason for our decision to actively } \\
\text { manage the land. }\end{array}$} \\
\hline \multicolumn{5}{|l|}{$\begin{array}{l}\text { The ICFWP has no influence on how we manage the } \\
\text { environmental features of this property }\end{array}$} \\
\hline \multicolumn{5}{|l|}{$\begin{array}{l}\text { Without the ICFWP our woodlot/property would not be } \\
\text { affordable }\end{array}$} \\
\hline \multicolumn{5}{|l|}{$\begin{array}{l}\text { We consider the ICFWP as largely compensation for } \\
\text { property taxes which are already too high }\end{array}$} \\
\hline \multicolumn{5}{|l|}{$\begin{array}{l}\text { The amount of compensation available through the ICFWP } \\
\text { makes it worthwhile to participate }\end{array}$} \\
\hline \multicolumn{5}{|l|}{$\begin{array}{l}\text { If there was no financial compensation (reduction in tax bill) } \\
\text { I/we would not participate in the ICFWP }\end{array}$} \\
\hline \multicolumn{5}{|l|}{ The ICFWP is effective for promoting biodiversity } \\
\hline $\begin{array}{l}\text { The ICFWP is effective in helping maintain/conserve Indiana } \\
\text { forests }\end{array}$ & & & & \\
\hline
\end{tabular}

\section{Part E: Background Information}

1. How many times during the past 12 months have you visited the following places?
A State Park: times
A State Forest: times
A National Forest: times

2. Please check all the ways you have used or managed your ICFWP and adjacent land(s) that are not in the program:

$\square$ Permanent residence for you and/or your family

$\square$ Seasonal residence for you and /or your family

$\square$ Crop farming or gardening for personal consumption

Crop farming for market sale

$\square$ Livestock raising for personal consumption

$\square$ Livestock raising for market sale

Do you consider your crops or livestock
"organic"?
$\square$ Yes $\square$ No

$\square$ Recreation (e.g. hiking, ATV use, etc.)

$\square$ Hunting or fishing (by you or someone else)

$\square$ Timber harvesting (by you or someone else)

$\square$ Harvesting wild foods for personal consumption

$\square$ Harvesting wild foods for market sale

(e.g. ginseng, walnuts, berries, etc.)

$\square$ Firewood harvesting (outside of top removal)

$\square$ Leased some of the land 
3. Are there any other land uses not listed above (question 2) that you would like to include?

4. Conservation easements are permanent legal agreements that limit future land development while leaving land in private ownership and on the local tax toll. Conservation easements are primarily used for preservation of ecological values of land for future generations.
Were you aware of conservation easements before today?
$\square$ Yes $\square$ No
Is any of your land under a conservation easement?
$\square$ Yes $\square$ No
If not, would you consider a conservation easement for your land?
$\square$ Yes $\square$ No

5. Do you consider yourself an environmentalist? $\quad \square$ Yes $\quad \square$ No

6. Please indicate your level of agreement with the following statement:

"The landscape in the county where my land is has changed a lot since I moved (or purchased property) there."

$\square$ strongly Agree

$\square$ somewhat Agree

$\square$ somewhat Disagree

$\square$ strongly Disagree

$\square$ Don't know or no opinion

7. To what extent would you say you were/are active or inactive in outdoor recreational activities like hiking, camping, boating, or hunting (not including organized team sports like soccer or hockey) as a teenager and as an adult?

\begin{tabular}{|l|l|l|l|l|}
\hline & Very Active & Somewhat Active & Somewhat Inactive & Very Inactive \\
\hline As a teenager & & & & \\
\hline As an adult & & & & \\
\hline
\end{tabular}

8. When you were growing up ( $0-18$ years of age), what best describes the place or places where you lived?

9. Are you a member, donor, or participant in any organizations that focus on environmental issues?
$\square$ Yes
$\square$ No
If so, which organization(s)?

10. Would you have participated in the ICFWP without the accompanying reduction in your property tax bill?

$\square$ Yes $\quad \square$ No $\square$ N/A, I have never participated in the ICFWP.

11. Are there other types of incentives or measures you would like to see or believe would be effective for promoting environmental stewardship on private lands? Please list up to three recommendations in the spaces below. 


\section{Part F: Demographic Information}

1. What is your age?

2. What is your gender?

$\square$ Female

$\square$ Male

$\square$ Other

3. Which of the following best describes your household?
$\square \quad$ Single adult living alone
$\square$ Adult couple living alone
$\square$ Single adult with child or children
$\square$ Adult couple with child or children
$\square$ Two or more unrelated adults
$\square$ Three or more related adults

4. Which of the following best describes your educational background?
$\square$ Some grade school or high school
$\square$ Professional degree (i.e. MD, JD, DVM)
$\square$ High school diploma or GED
$\square$ University graduate degree (i.e. MA, MS,
$\square$ Some college/university/technical school $\mathrm{PhD}$ )
$\square$ Technical school diploma
$\square$ Other:
$\square$ Bachelor's degree (i.e. BA, BS)

5. Which of the following best describes your employment status? (Check multiple categories, if needed)
$\square$ Homemaker
$\square$ Employed full-time
$\square$ Employed part-time
$\square$ Retired
$(30+\mathrm{hrs} / \mathrm{wk})$
$(<30 \mathrm{hrs} / \mathrm{wk})$
$\square$ Student
$\square \quad$ Unemployed
$\square$ Other:

6. What ethnicity do you most identify with?

7. What category best describes your household income for 2013 ?
$\square \quad \$ 0-\$ 25,000$
$\square \quad \$ 75,000-\$ 100,000$
$\square \$ 200,000-\$ 250,000$
$\square \quad \$ 25,000-\$ 50,000$
$\square \$ 100,000-\$ 150,000$
$\square \quad \$ 250,000-\$ 300,000$
口 $\$ 50,000-\$ 75,000$
$\square \$ 150,000-\$ 200,000$
$\square \$ 300,000+$

8. Would you be willing to participate in a follow up telephone interview? If yes, please provide your phone number in the space below and best time for us to reach you:

9. Do you have any further comments or information that you would like to share about this survey and other related issues? 